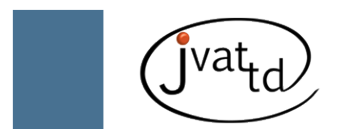

\title{
"Vitalis Brazilis", burning embers, beyond the ashes, at the Butantan Institute
}

De Lima ME (1)

(1) President of the Brazilian Society of Toxinology; Laboratory of Venoms and Animal Toxins, Department of Biochemistry and Immunology, Institute of Biological Sciences, Federal University of Minas Gerais, Belo Horizonte, Minas Gerais State, Brazil.

\section{Dear Editor,}

The fire at the Butantan Institute (IBU Instituto Butantan) represent a profound shock to the Brazilian Society of Toxinology (SBTx Sociedade Brasileira de Toxinologia), and has affected its origins, its history, its patrimony and its living soul - the toxinologists.

Hitherto, nothing similar has been registered in the last twenty-two years of the existence of this society, founded by a group of toxinologists that inherited from Vital Brazil an innate interest in this area, in which the actors - poisonous animals, plants and microorganisms - integrate the vast Brazilian biodiversity. Among these first toxinologists was Vital Brazil's son, Dr. Osvaldo Vital Brazil, who, besides being one of the founders of SBTx, was its first president, which allowed him to maintain the pioneering work of his father. For this reason, we may believe that SBTx bears the signature and the genuine inheritance from Vital Brazil Mineiro da Campanha, one of the founders of toxinology in Brazil. On the Butantan farm, Vital Brazil (the father) started his studies on snake poisoning, creating tools and new treatments, advising the population, preserving the first collected specimens of poisonous animals, encouraging people and promoting methods to collect these animals, a process that frequently caused accidents. In a few minutes, a great part of this collection, which has been increased, maintained and preserved for more than a century, became ashes.
There has been indignation, lamentation and protests that were broadcasted last May, right after the fire. SBTx accompanied and took part in this movement. But above all, this society invites its associates to never forget this shock, to repudiate the lack of care/responsibility towards our patrimony (by the government or by some individuals), but without passing judgment on anyone.

We should remember, however, that Vital Brazil never gave up when he faced countless challenges in a time of no resources, little knowledge and great problems involving plagues and accidents with poisonous animals. We should remember that "Vitalis Brazilis", a burning ember, still remains, despite the transformation of the ruined collection into ashes! Butantan Institute, with its various research groups and its staff of competent researchers, certainly keeps the indestructible "flame" of Vital Brazil.

This is an invitation for reconstruction. A lot was lost, but can we reconstruct it? Agencies such as CAPES, CNPq and state foundations for research support will certainly assist in meeting this demand. SBTx reaffirms the necessity of prioritizing the recovery of this patrimony that belongs to Brazilian science with concrete initiatives of public and private investments, which will guarantee the continuity of studies in the fire-affected areas at IBU.

This society hereby launches the campaign: "Vitalis Brazilis" - IBU Fellows for the restructuring of its collection. 
The tangible suggestion involves the organization of regional groups that would be committed to sending specimens of poisonous animals from their respective regions to the Butantan Institute, in an effort to recompose a new scientific collection. SBTx is ready to help in this process, together with the IBU Fellows. The meetings of the society could be a forum for a periodical report on this reconstruction and on the participation of its associates in this job! The challenge is launched.

\section{COPYRIGHT}

(C) CEVAP 2010

\section{SUBMISSION STATUS}

Received: June 25, 2010.

Accepted: June 25, 2010.

Full paper published online: August 31, 2010.

\section{CONFLICTS OF INTEREST}

There is no conflict.

\section{CORRESPONDENCE TO}

MARIA ELENA DE LIMA, Laboratório de Venenos e Toxinas Animais, Departamento de Bioquímica e Imunologia, Instituto de Ciências Biológicas, Universidade Federal de Minas Gerais, Av. Antonio Carlos, 6627, Belo Horizonte, MG, 31.270-901, Brasil. Phone: +55 3134092659. Email: melenalima@icb.ufmg.br. 